\title{
Zinc Finger and BTB Domain-Containing Protein 46
}

National Cancer Institute

\section{Source}

National Cancer Institute. Zinc Finger and BT B Domain-Containing Protein 46. NCI

Thesaurus. Code C131773.

Zinc finger and BTB domain-containing protein 46 (589 aa, $\sim 64 \mathrm{kDa}$ ) is encoded by the human ZBTB46 gene. This protein plays a role in the negative regulation of PR domain zinc finger protein 1 expression. 